\title{
Evaluation of Available Soil Nutrients and Nitrogen Fixing Bacterial Population in Rhizosphere of Wild Grasses From agricultural land of Newasa Tahasil of Ahmednagar District (MS) India
}

\author{
Takate B.D ${ }^{1}$, Gaykar B.M² \& Nisha H.Godse ${ }^{3}$ \\ ${ }^{I}$ Soil \& Water Testing and Biofertilizers laboratory, Loknete Marutrao Ghule Patil Dnyaneshwar Sahakari Sakhar Karkhana Ltd., \\ Bhende, Maharashtra, India. \\ ${ }^{2,3}$ P.G. Department of Botany, Ahmednagar College, Ahmednagar, Maharashtra, India.
}

DOI: $10.38177 /$ ajast.2020.4305

\section{ABSTRACT}

Soil is a wonderful gift of nature for living creatures. It supports crop growth. It is an important environmental factor, and has a close reciproca relationship with the plants growing in it and the soil microbes that exist in it. The forest soil consists of high humus with variety of microbes. In this experiment forest area of Newasa was selected for evaluation of nutrient status and bacterial population. On the basis of density of grasses Iseileme prostratum L, Setaria pumila (Poir.) Roem. \& Schult, Aristida hystrix L., Dactyloctenium aegyptium (L.) Willd, Fimbriristylis miliacea (L.) Vahl were selected. 100 soil samples from different locations from rhizosphere of these monocots were collected and analyzed for soil nutrient status and nitrogen fixing bacterial population. It was recorded that, out of five plants, the rhizosphere soil of Setaria pumila L. showed maximum bacterial population (11700540.00). Available nitrogen (320 kg/ha) and \% organic carbon (0.60\%) followed by Setaria pumila (Poir.) Roem. \& Schult the bacterial population was (2558265.00), available nitrogen (203 Kg/ha) and \% Organic Carbon $(0.59 \%)$. Other soil nutrients were also measured.

Keywords: Monocots, Nutrient status, Bacterial population, Available nitrogen, \% Organic carbon.

\section{Introduction}

Soil generally contains variety of nutrients required for plants. Nutrient content in agricultural lands is slowly reduced because it is absorbed by plants to meet its growth needs (Sutejo et al. 1991). Manure can improve the physical, chemical and biological properties of soil through its role as a source of food for microbes in the soil (Sugito et al. 1995) and increase the varieties of microbes and populations (Sarief, 1989).

Soil plays an important role in the mineral cycles viz. nitrogen, phosphorus, sulfur and carbon cycles. The bacteria that play roles in the nitrogen cycle are Azotobacter. Azotobacter, for example, is the bacteria that live in rhizosphere areas which are heterotrophic. These bacteria bind free nitrogen which influence the physical and chemical properties and increase soil fertility. The population of nitrifying bacteria in the soil affects the concentration ratio of nitrogen in the soil, so that the microbial population is an indicator of soil fertility levels (Allen and Allen, 1981). The use of manure can improve soil fertility for a longer period of time. Soil physico-chemical characteristics influence the composition of the soil microbial community, their activity and the level of microbial mass (Dick, 1994).

Newasa tahasil is present in Ahmednagar district (MS) India. In this Tahasil 91.1\% land, is under agriculture and $1.02 \%$ land under forest. Forest soil is not contaminated; there is no use of chemical fertilizers and pesticides. Hence the soil was selected to evaluate the available nutrient status and population density of nitrogen fixing bacteria. With this view we select five wild monocots to evaluate nitrogen fixing bacterial population from their rhizosphere soil and available plant nutrients. The survey of the forest grasses was done. On the basis of density, grasses viz. Iseilema prostratum L, Setaria pumila (Poir.) Roem.\& Schult, Aristida hystrix L., Dactyloctenium aegyptium (L.) Willd, and Fimbriristylis miliacea (L.) Vahl. were selected. 


\section{Materials and Methods}

\section{Collection of Soil Samples}

The 100 soil samples were collected in June 2016 from rhizosphere of monocotyledons. five monocots designated as 1A, 2A, 3A, 4A, 5A which were identified from Botanical survey of India Gov. of India Ministry of Environment, Forest and Climate change western regional centre, Koregaon road, Pune viz. Iseilema prostratum L. (1A), Setaria pumila (Poir.) Roem. \& Schult.(2A), Aristida hystrix L.(3A), Dactyloctenium aegyptium (L.) Willd. (4A), Fimbriristylis miliacea (L.) Vahl. (5A). 20 soil samples from each monocot at 20 different places of forest area of Newasa tahasil of Ahmednagar district Maharashtra state India were collected. These soil samples were placed in sterile bags, numbered and carried to the laboratory and stored in a refrigerator prior to processing.

\section{Culture media}

Jensen's agar Medium (Jensen 1965) was used for the evaluation of nitrogen fixing Bacterial population. It contained (g/liter) Sucrose $20 \mathrm{~g}$, di-potassium hydrogen phosphate $1 \mathrm{~g}$, magnesium sulfate $0.5 \mathrm{~g}$, sodium chloride $0.5 \mathrm{~g}$, ferrous sulfate $0.1 \mathrm{~g}$, sodium molybdate $0.005 \mathrm{~g}, 1$ tablet of flucanozole 500mg, Agar $20 \mathrm{~g}, \mathrm{pH}$ (ph.7.1 \pm 0.2 ) of culture media was adjusted by using $1 \mathrm{~N} \mathrm{NaOH}$ or $1 \mathrm{~N} \mathrm{H}_{2} \mathrm{So}_{4}$. Media was sterilized by autoclaving at $120^{\circ} \mathrm{c}$ temperature, $15 \mathrm{lb}$ pressure for 15 - 20 minutes.

\section{Isolation}

The collected soil samples were used for the culturing of nitrogen fixing microorganisms on Jensen's nitrogen free Agar medium by serial dilution agar plate technique (Aneja 2002). Ten gram of soil from each sample was aseptically weighed and transferred to $250 \mathrm{ml}$ conical flask containing $90 \mathrm{ml}$ of sterile double distilled water. The flasks were shaked in orbital shaker at $200 \mathrm{rpm}$ for 30 minutes. Samples were allowed to settle for 1 minute. Aliquots of $1 \mathrm{ml}$ of the supernatant from the samples were transferred to $9 \mathrm{ml}$ of $(0.85 \% \mathrm{NaCl})$ saline solution in test tube and serially diluted up to $10^{-7} .2 \mathrm{ml}$ of sample from each of these dilutions was transferred to sterilized 18 $\mathrm{ml}$ of Jensen's agar medium before solidification $\left(45^{\circ} \mathrm{C}\right.$ temperature $)$ and poured in sterile Petri dish after mixing. After solidification, plates were kept in an incubator at $28^{0} \mathrm{C}( \pm 2)$ for 4-5 days. After incubation grown microbial colonies were counted on colony counter.

\section{Analysis of collected soil samples}

The collected rhizosphere soil samples of selected five monocots were analyzed for $\mathrm{pH}$ and Electrical conductivity (Thomas 1996), \% Organic Carbon (Walkley Black Method 1947), Available Nitrogen Kg/ h (Alkaline permanganate method 1956), Available Phosphates Kg /h (Ascorbic acid method 1954), Available Potassium Kg/h (Ammonium Acetate method Thomas 1982), Available Zn, Fe, Mn, Cu. DTPA-TEA method (Lindsay and Norvell 1978 ). The method consists of use of DTPA (Diethylene tetra amine penta acetic acid) as an attractants which has been widely accepted for the simultaneous extraction of metal micronutrient cations viz., zinc ( $\mathrm{Zn})$, copper $(\mathrm{Cu})$, iron $(\mathrm{Fe})$, and manganese $(\mathrm{Mn})$ in neutral and alkaline soils.

The contents of these cations in the extract were determined on an Atomic Absorption Spectrophotometer. (A.A.S) 
Asian Journal of Applied Science and Technology

Volume 4, Issue 3, Pages 29-36, July-September 2020

The enumeration of Azotobacter was done by serial dilution method. The soil samples were inoculated on nitrogen free Jensen's Agar medium, were kept for incubation. These plates were analyzed for total viable count of bacteria by serial dilution method

\section{Result Table:-}

Table No 6: Chemical Analysis of soil and nitrogen fixing bacterial population in Rhizosphere of four Wild grasses $\&$ one sedge plant of forest area of Newasa tahasil, Dist. Ahmednagar (MS)

\begin{tabular}{|c|c|c|c|c|c|c|c|c|c|c|c|}
\hline 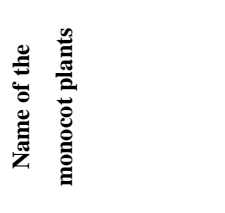 & $\stackrel{7}{2}$ & 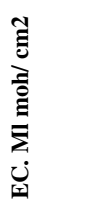 & 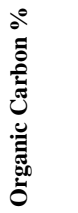 & 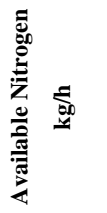 & 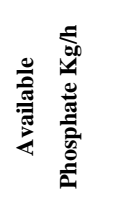 & 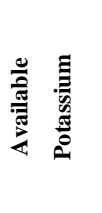 & $\begin{array}{l}\Xi \\
\vdots \\
\vdots \\
0 \\
0\end{array}$ & $\begin{array}{l}\Xi \\
\vdots \\
\Xi \\
\Xi \\
\Xi\end{array}$ & 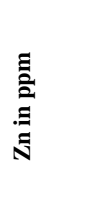 & 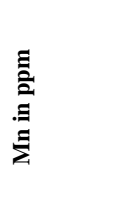 & 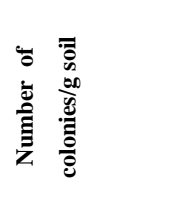 \\
\hline $\begin{array}{c}\text { Iseilema prostratum } \\
\mathrm{L} .\end{array}$ & $\begin{array}{l}7.43 \mathrm{a} \\
\pm 0.07\end{array}$ & $\begin{array}{l}0.45 \mathrm{a} \\
\pm 0.05\end{array}$ & $\begin{array}{l}0.59 \mathrm{a} \\
\pm 0.09\end{array}$ & $\begin{array}{l}203.75 \mathrm{a} \\
\pm 41.73\end{array}$ & $\begin{array}{l}8.42 \mathrm{a} \\
\pm 1.23\end{array}$ & $\begin{array}{l}352.46 \mathrm{a} \\
\pm 23.95\end{array}$ & $\begin{array}{l}2.88 \mathrm{a} \\
\pm 0.31\end{array}$ & $\begin{array}{l}0.53 \mathrm{a} \\
\pm 0.11\end{array}$ & $\begin{array}{l}0.57 \mathrm{a} \\
\pm 0.12\end{array}$ & $\begin{array}{l}1.97 \mathrm{a} \\
\pm 0.28\end{array}$ & $2558265.00 \mathrm{a}$ \\
\hline $\begin{array}{l}\text { Setaria pumila } \\
\text { (Poir.) Roem.\& } \\
\text { Schult. }\end{array}$ & $\begin{array}{l}7.41 \mathrm{ab} \\
\pm 0.06\end{array}$ & $\begin{array}{c}0.43 \mathrm{ab} \\
\pm 0.03\end{array}$ & $\begin{array}{l}0.60 \mathrm{a} \\
\pm 0.13\end{array}$ & $\begin{array}{l}320.05 \mathrm{~b} \\
\pm 23.53\end{array}$ & $\begin{array}{l}0.43 \mathrm{~b} \\
\pm 0.03\end{array}$ & $\begin{array}{l}352.74 \mathrm{a} \\
\pm 30.64\end{array}$ & $\begin{array}{l}2.52 \mathrm{a} \\
\pm 0.22\end{array}$ & $\begin{array}{l}0.81 \mathrm{~b} \\
\pm 0.13\end{array}$ & $\begin{array}{l}0.28 \mathrm{~b} \\
\pm 0.05\end{array}$ & $\begin{array}{l}0.80 \mathrm{~b} \\
\pm 0.14\end{array}$ & $11700540.00 \mathrm{~b}$ \\
\hline Aristida hystrix $\mathbf{L}$. & $\begin{array}{l}7.59 \mathrm{ac} \\
\pm 0.10\end{array}$ & $\begin{array}{l}0.51 \mathrm{a} \\
\pm 0.06\end{array}$ & $\begin{array}{l}0.51 \mathrm{a} \\
\pm 0.10\end{array}$ & $\begin{array}{l}198.05 \mathrm{a} \\
\pm 14.44\end{array}$ & $\begin{array}{l}5.65 \mathrm{c} \\
\pm 0.77\end{array}$ & $\begin{array}{l}321.54 \mathrm{a} \\
\pm 26.41\end{array}$ & $\begin{array}{l}2.51 \mathrm{a} \\
\pm 0.22\end{array}$ & $\begin{array}{l}0.78 \mathrm{~b} \\
\pm 0.17\end{array}$ & $\begin{array}{l}0.59 \mathrm{ac} \\
\pm 0.04\end{array}$ & $\begin{array}{l}1.13 \mathrm{c} \\
\pm 0.19\end{array}$ & $1659650.00 \mathrm{c}$ \\
\hline $\begin{array}{c}\text { Dactyloctenium } \\
\text { aegyptium }(\mathrm{L} .) \text { Willd. }\end{array}$ & $\begin{array}{l}7.49 \mathrm{ad} \\
\pm 0.04\end{array}$ & $\begin{array}{l}0.60 \mathrm{c} \\
\pm 0.05\end{array}$ & $\begin{array}{l}0.50 \mathrm{a} \\
\pm 0.12\end{array}$ & $\begin{array}{l}182.95 \mathrm{a} \\
\pm 24.39\end{array}$ & $\begin{array}{l}7.95 \mathrm{a} \\
\pm 0.78\end{array}$ & $\begin{array}{l}317.56 \\
\pm 19.71\end{array}$ & $\begin{array}{l}2.40 \mathrm{~b} \\
\pm 0.25\end{array}$ & $\begin{array}{l}0.67 \mathrm{a} \\
\pm 0.08\end{array}$ & $\begin{array}{l}0.66 \mathrm{ac} \\
\pm 0.05\end{array}$ & $\begin{array}{l}0.81 \mathrm{~b} \\
\pm 0.10\end{array}$ & $1454440=00 \mathrm{c}$ \\
\hline $\begin{array}{c}\text { Fimbristylis miliacea } \\
\text { (L.)Vahl }\end{array}$ & $\begin{array}{l}7.50 \mathrm{ad} \\
\pm 0.08\end{array}$ & $\begin{array}{c}0.50 \mathrm{ab} \\
\pm 0.04\end{array}$ & $\begin{array}{l}0.49 \mathrm{a} \\
\pm 0.09\end{array}$ & $\begin{array}{l}178.10 \mathrm{a} \\
\pm 21.47\end{array}$ & $\begin{array}{l}7.84 \mathrm{a} \\
\pm 0.49\end{array}$ & $\begin{array}{l}290.10 \mathrm{~b} \\
\pm 24.41\end{array}$ & $\begin{array}{l}2.44 \mathrm{~b} \\
\pm 0.21\end{array}$ & $\begin{array}{l}0.66 \mathrm{a} \\
\pm 0.11\end{array}$ & $\begin{array}{c}0.52 \mathrm{acd} \\
\pm 0.04\end{array}$ & $\begin{array}{l}1.89 \mathrm{c} \\
\pm 0.16\end{array}$ & $493530.00 \mathrm{c}$ \\
\hline CD at $0.05 \%$ & 0.12 & 0.08 & 0.18 & 44.65 & 1.28 & 42.29 & 0.41 & 0.2 & 0.11 & 0.3 & \\
\hline P-value at $0.05 \%$ & 0.43 & 0.12 & 0.92 & 0.001 & $2.05 \mathrm{E}-11$ & 0.36 & 0.67 & 0.51 & 0.001 & $9.14 \mathrm{E}-07$ & 0.16 \\
\hline
\end{tabular}

(Where Mean values are of average of twenty readings. Data was analysed using single factor ANOVA at $0.05 \%$ P-value followed by CD at $0.05 \%$ and Tukey's test. \pm : standard error of means.)

Graph NO 1 (A): Soil analysis of rhizosphere of wild monocots from forest area of Newasa tahasil, Dist. Ahmednagar

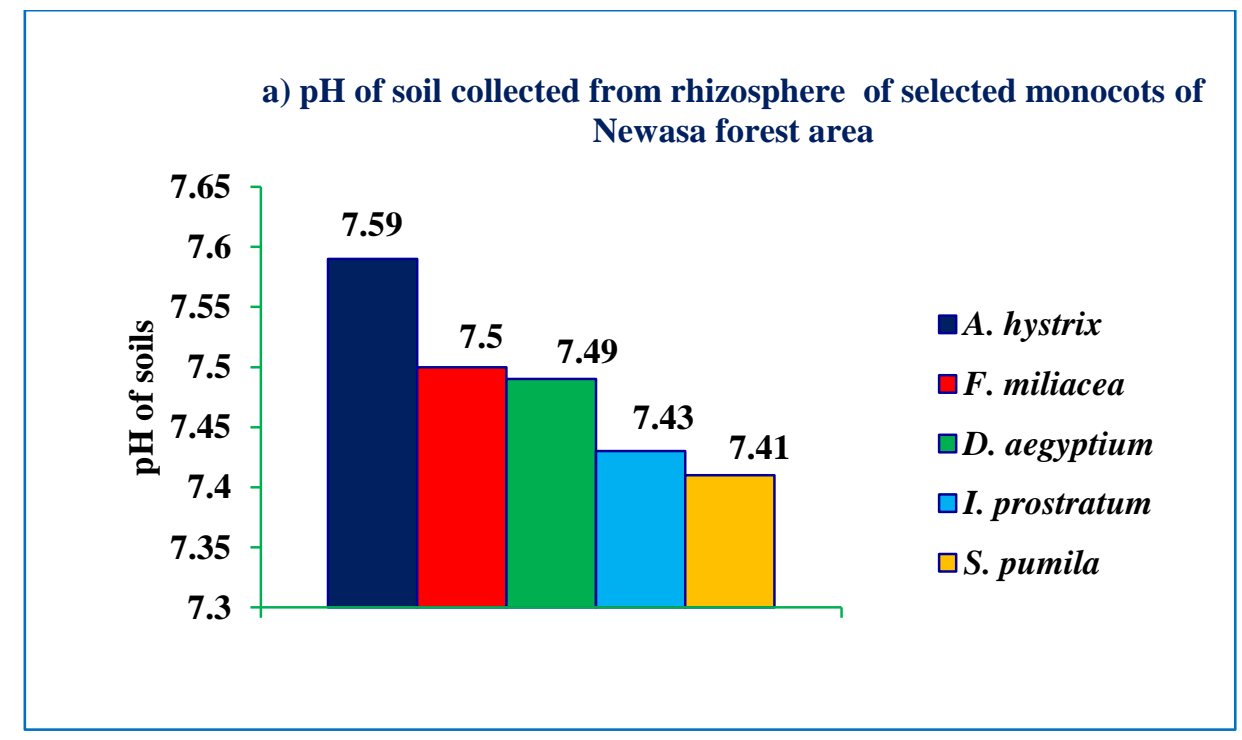


b) EC of soil collected from rhizosphere of selected monocots of Newasa forest area

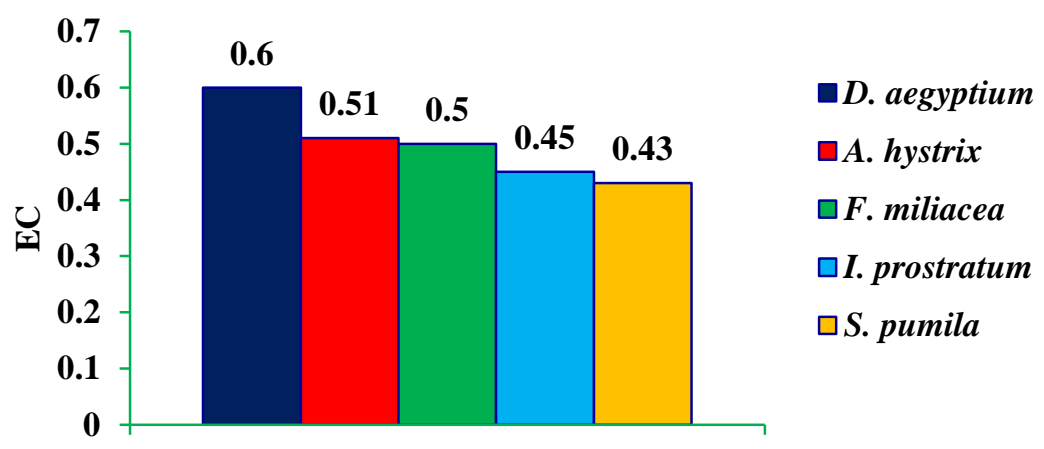

c) \% organic Carbon in soil collected from rhizosphere of monocots of Newasa forest area

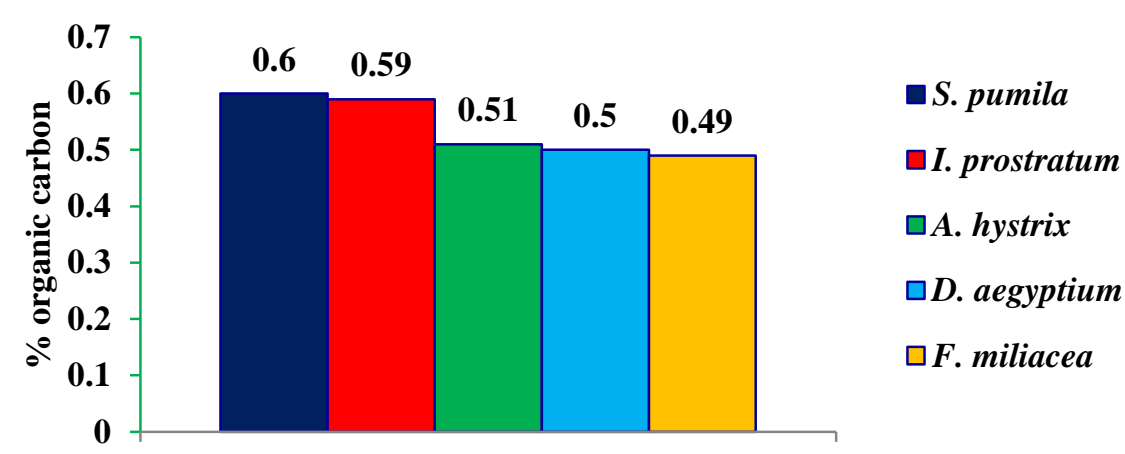

Where: Iseilema prostratum L.; Setaria pumila (Poir.) Roem. \& Schult. ; Aristida hystrix L.; Dactyloctenium aegyptium (L.) Willd. And Fimbristylis miliacea (L.) Vahl

Graph NO 1(B): Soil analysis of rhizosphere of wild monocots of forest area of Newasa tahasil, Dist. Ahmednagar (MS)

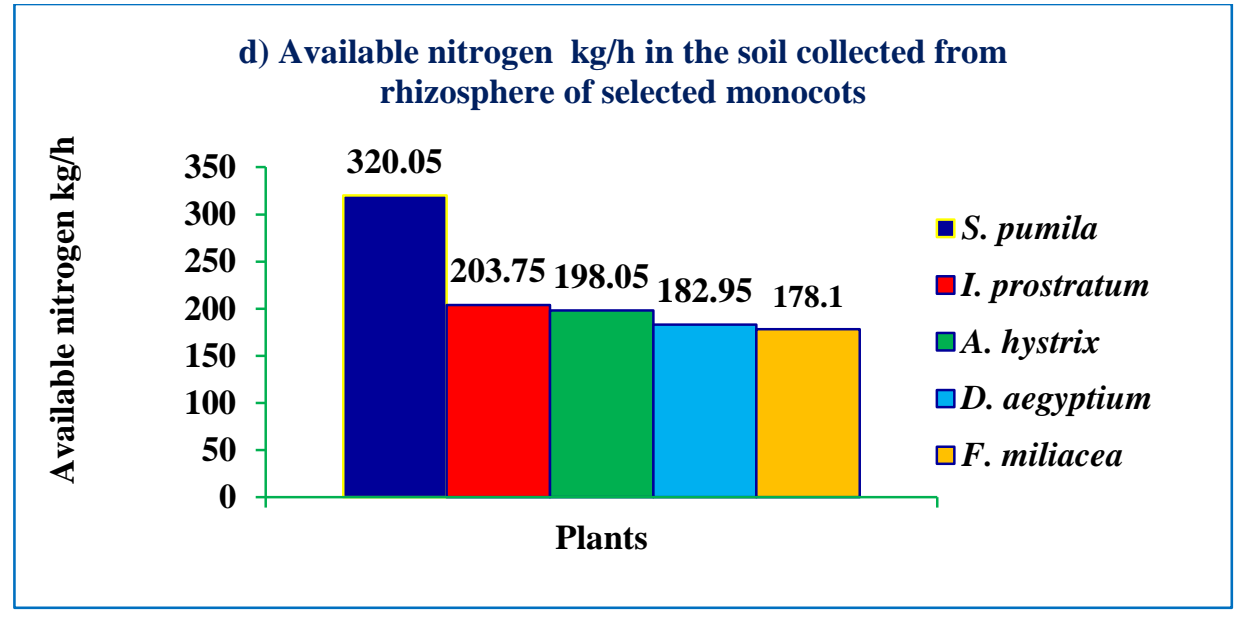



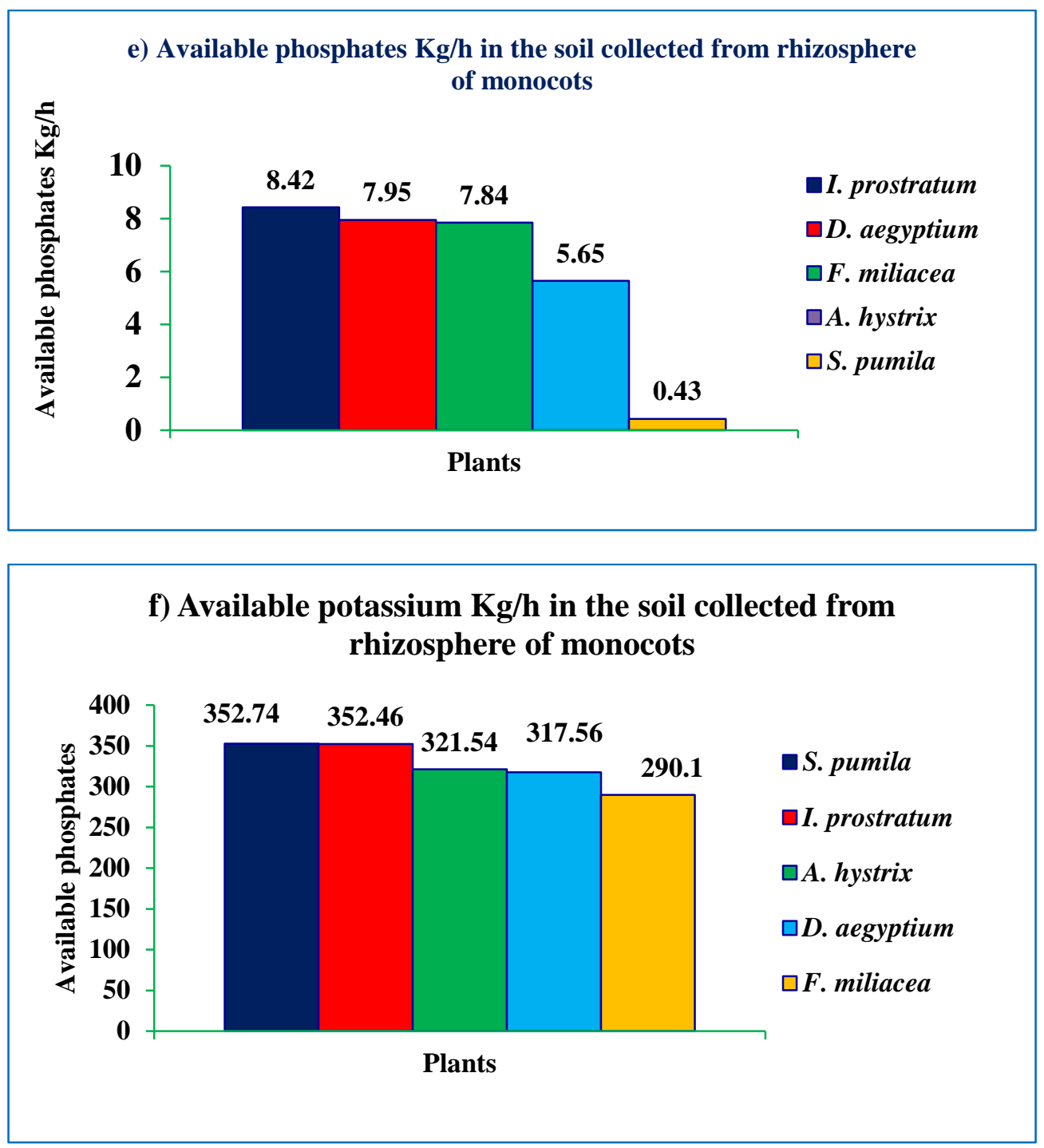

Where: I: Iseilema; S: Setaria.; A:ristida; D: Dactyloctenium and F: Fimbristylis

Graph NO 1(C): Soil analysis of Rhizosphere of Wild Monocots of forest area of Newasa tahasil, Dist.

Ahmednagar (MS) India

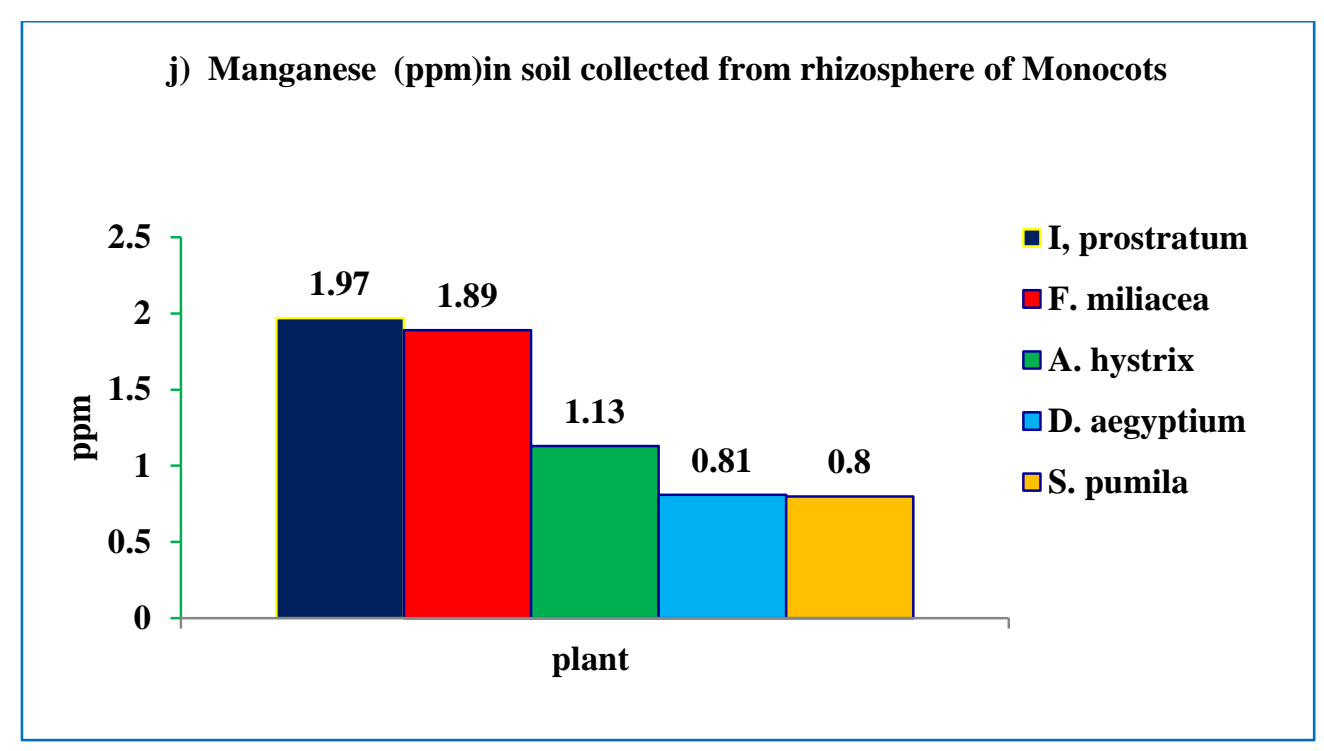


Where: Iseilema prostratum L.; Setaria pumila (Poir.) Roem. \& Schult. ; Aristida hystrix L.; Dactyloctenium aegyptium (L.) Willd. and Fimbristylis miliacea (L.) Vahl

\section{Result and Discussion}

The concentration of nitrogen ratio in the soil is affected by the population of nitrifying bacteria in the soil (Deokar, 2015). Mujiyatil, and Supriyadi,(2009) reported that, the sandy clay loam, sandy loam, and loam showed the highest bacterial populations Azotobacter population, without any treatment reached the mean of $4333.33 \mathrm{cfu} / \mathrm{mg}$, whereas Azotobacter population, with NPK treatment reached the mean of $6666.67 \mathrm{cfu} / \mathrm{mg}$. From these observations, it can be concluded that the giving of NPK may increase the population of Azotobacter to the highest value as compared to control. Azotobacter population got higher value when compared with manure was understandable due to the granting of NPK fertilizer that can decrease soil $\mathrm{pH}$ to 6.31 compared to soil $\mathrm{pH}$ with manure treatment which was 7.08 and with no treatment (control) which was 7.08 .

Rao (1994) reported that, Azotobacter bacteria are commonly found in neutral or acid soil. Azotobacter has a beneficial effect in the rate of seed development, plant growth, standing crop and vegetative growth with the increase in Azotobacter.

Boddey and Dobereiner (1995) reported that improvement of nutrient uptake and plant nutritional status can be achieved by using selective bacteria as observed with legumes and grasses. Soil $\mathrm{pH}$ of rhizosphere of grasses and a sedge plant: Twenty readings were taken and collected data was subjected to single factor ANOVA analysis. $\mathrm{pH}$ of soils collected from rhizosphere of grasses and a sedge plant were not significantly different at $05 \%$ p-level. $\mathrm{pH}$ of

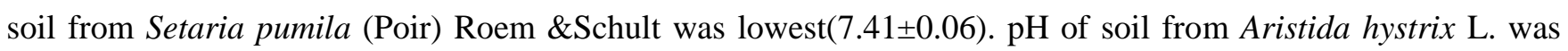
highest $(7.59 \pm 0.10)$.

$\mathrm{pH}$ of soil from a sedge plant of Cyperaceae family Fimbristylis miliacea (L.) Vahl. was (7.50 \pm 0.08 ). Soils were not too much alkaline. Electric conductivity MI Moh/ $\mathrm{cm}^{2}$ in the rhizosphere was in the range of 0.43 to 0.60 . Soil organic carbon \% in soil samples was in range of 0.49 to 0.60 . Available potassium $\mathrm{kg} / \mathrm{h}$ in a range of 290.10 to $352.46 \mathrm{Kg} / \mathrm{h}$.Fe (ferrous form) in ppm in a range of $2.40 \mathrm{ppm}$ to $2.88 \mathrm{ppm} . \mathrm{Cu}$ (ppm) was in a range of 0.53 to 0.81 . Electric conductivity, organic carbon $\%$, Available potassium $\mathrm{kg} / \mathrm{h}$ and $\mathrm{Cu}(\mathrm{ppm})$ were not significantly different (at $0.05 \% \mathrm{P}-$ level) in the rhizosphere of all five monocot plants.

Available nitrogen $\mathrm{Kg} / \mathrm{h}$ was significantly different in rhizospheres of all five plants. Analysis of Rhizosphere soil of Fimbristylis revealed lowest $(178.10 \mathrm{~kg} / \mathrm{h})$ available nitrogen while in the rhizosphere soil of Setaria pumila it was recorded highest $(320.05 \mathrm{~kg} / \mathrm{h})$. Available phosphates $\mathrm{Kg} / \mathrm{h}$ was in a range of $0.43 \mathrm{~kg} / \mathrm{h}$ to $8.42 \mathrm{~kg} / \mathrm{h}$. ppm; $\mathrm{Zn}$ (ppm) was in a range 0.28 to $0.66 \mathrm{ppm}$ and $\mathrm{Mn}$ (ppm) was in a range from 0.80 to $1.97 \mathrm{ppm}$. These were significantly different at $0.05 \%$ probability level. Number of bacterial colonies in the soils samples of rhizosphere of grasses was in a range of 1454440 to 11700540.

\section{Conclusions}

Soils from rhizospheres of five Monocot plants were not too much alkaline. Electric conductivity, organic carbon $\%$, Available potassium $\mathrm{kg} / \mathrm{h}$ and $\mathrm{Cu}(\mathrm{ppm})$ were not significantly different in the rhizosphere of all five monocot 
Asian Journal of Applied Science and Technology

Volume 4, Issue 3, Pages 29-36, July-September 2020

plants. Rhizosphere soil of Fimbristylis revealed lowest available nitrogen while Setaria pumila the highest. Available phosphates and $\mathrm{Zn}(\mathrm{ppm})$ were significantly different at $0.05 \%$ probability level. Bacterial colonies in the soils samples of rhizosphere of Setaria pumila (Poir.) Roem.\& Schult were maximum as compared to other four Monocots (Table No 1)

Acknowledgement: We are thankful to Dr. R. J Barnabas, Principal of Ahmednagar College, Ahmednagar for providing necessary facilities. Also thanks to Ex MLA Dr. Narendra Ghule Patil, Ex MLA Chandrashekar Ghule Patil, and Board of Directors and M.D. Anil P. Shewale G.M., Shinde K.A L.M.G.P. D.S.S.K. ltd. Bhende for providing Laboratory Facilities, Dr. R.G. Khose Former Head Dept. of Botany, New Arts Commerce and Science College, Ahmednagar for data analysis.

\section{References}

[1] Allen ON, Allen EK. (1981) The leguminosae: A source book of characteristics, uses, and nodulation, University of Wisconsin Press. Madison, USA.

[2] Deokar. S.C. (2015) Effect of Mangnous Oxide, Zinc Sulphate on plant growth promoting rhizobacteria Azotobacter chrococcum. International Journal of Scientific Engineering and Applied Science (IJSEAS) Volume-1, Issue-9, pp50-56

[3] Dick, R.P. (1994) Soil Enzyme Activities as Indicators of Soil Quality. In: Doran, J.W., Coleman, D.C., Bezdicek, D.F. and Stewart, B.A., Eds., Defining Soil Quality for a Sustainable Environment, Soil Science Society of America.

[4] Rao NSS. (1982) Biofertilizers in agriculture. Oxford and IBH Publishers. New Delhi.

[5] Rao NSS. (1994) Soil microorganisms and plant growth. UI Press. Jakarta. [Indonesia].

[6] Sarief S. (1989) Fertility and fertilization of agricultural land. Pustaka Buana. Bandung. [Indonesia]

[7] Sugito Y, Nuraini Y, Nihayati E. (1995) Organic farming systems. Faculty of Agriculture. Brawijaya University. Malang. [Indonesia]

[8] Lindsay, W.L. and Norvell. (1978)Development of a DTPA soil tests for Zn, Fe, Cu, and Mn Soil Sci. Soc. Am. J., $42: 421-428$

[9] Thomas G.S. (1996) Soil pH and Soil acidity p. 475-490. In methods of Soil Analysis. Parts. Chemical Methods (Ed.) DL Sparts, SSSA ASA, Madison WI.

[10] Thomas G.S. (1996) Soil Electrical conductivity p. 475-490. In methods of Soil Analysis. Parts. Chemical Methods (Ed.) DL Sparts, SSSA ASA, Madison WI.

[11] Walkley A. (1947) A critical examination of rapid method for determining organic carbon in soil: effect of variations in digestion condition and organic soil constituents soil science. 63; 251-263. In Somawanshi R, Kadlag A, Deshpande A, Tamboli B, 2012 Soil and water testing methods soil science and Agricultural chemistry Mahatma phule Krushi vidhyapeeth Rahuri Ahmednagar MS India. 
[12] Subbiah B.V. and Asija G.I. (1956) A rapid procedure for the estimation of available nitrogen in soil current science 25; 259- 260. In Somawanshi R, Kadlag A, Deshpande A, Tamboli B, (2012) Soil and water testing methods soil science and Agricultural chemistry Mahatma phule Krushi vidhyapeeth Rahuri Ahmednagar MS India.

[13] Olsen S.R. Cole C.V. Watanable F.S. and Dean L.R. (1954) Estimation of available phosphate in soil by extraction with sodium bi carbonate VSDA circular 939 VSDA Washington D.C. In Somawanshi R, Kadlag A, Deshpande A, Tamboli B, (2012) Soil and water testing methods soil science and Agricultural chemistry Mahatma phule Krushi vidhyapeeth Rahuri Ahmednagar MS India.

[14] Thomas G.W. (1982) Exchangeable cations p159-165 In Page A.L. et al. (ed) Methods of soil Analysis part 2 second (ed) Agron monger and ASA and SSSA Madison W.I. In Somawanshi R, Kadlag A, Deshpande A, Tamboli B, (2012) Soil and water testing methods soil science and Agricultural chemistry Mahatma phule Krushi vidhyapeeth Rahuri Ahmednagar MS India.

[15] Lindsay W.L. and Narvell W.A. (1978) Development of a DTPA soil test for Zn, Fe, Cu and Mn Soil Science AM 5. 42: 421-428 In Somawanshi R, Kadlag A, Deshpande A, Tamboli B, (2012) Soil and water testing methods soil science and Agricultural chemistry Mahatma phule Krushi vidhyapeeth Rahuri Ahmednagar MS India.

[16] Aneja K.R. (2002) Experiments in Microbiology, Plant Pathology, Tissue Culture and Mushroom production technology New Age international p. Ltd. New Delhi. PP 632. 